\title{
Potensi Jamur Tanah dan Mikoriza dalam Menekan Perkembangan Penyakit Layu Pada Bibit Pala (Myristica fragrans Houtt) di Maluku
}

\section{Potency of Soil Fungi and Mycorrhiza in Suppressing the Development of Wilt Disease in Nutmeg (Myristica fragrans Houtt) Seed in Moluccas}

\author{
Sarjoko $^{1 *}$, Syamsuddin Djauhari ${ }^{2}$, Anton Muhibuddin $^{2}$ \\ ${ }^{1}$ Program Magister Agronomi, Fakultas Pertanian, Universitas Brawijaya \\ 2 Jurusan Hama dan Penyakit Tumbuhan, Fakultas Pertanian, Universitas Brawijaya
}

\begin{abstract}
Abstrak
Kematian bibit akibat serangan penyakit layu bibit pala dirasakan sangat merugikan bagi para penangkar bibit. Jamur tanah telah dilaporkan dapat menekan perkembangan berbagai patogen tular tanah. Mikoriza adalah bentuk asosiasi jamur dengan tanaman yang memiliki kemampuan dalam meningkatkan ketahanan dan pertumbuhan tanaman. Tujuan penelitian adalah mengetahui jenis organisme penyebab penyakit layu pada bibit pala, mengetahui jenis-jenis jamur tanah yang berpotensi menekan perkembangan penyakit layu bibit pala dan mengetahui peranan mikoriza dalam meningkatkan ketahanan dan pertumbuhan tanaman. Penelitian dilakukan pada fase in vitro, fase perkecambahan dan pembibitan. Rancangan percobaan menggunakan Rancangan Acak Lengkap dengan tiga ulangan. Penyebab penyakit layu bibit pala adalah jamur Sclerotium rolfsii. Sebanyak 15 isolat jamur tanah diperoleh dari hasil eksplorasi. Hasil uji antagonisme secara in vitro menunjukkan bahwa terdapat 11 jamur tanah yang potensial menekan koloni jamur S. rolfsii secara signifikan. Empat isolat jamur tanah, yaitu jamur Candida sp, Trichoderma viride, Trichoderma harzianum, dan Botrytis sp.1 konsisten secara nyata mampu menekan perkembangan $S$. rolfsii mulai dari pengujian in vitro, perkecambahan sampai pembibitan. Dengan penambahan mikoriza, maka Botrytis sp. 2 mampu menekan jamur S. rolfsii secara signifikan pada fase perkecambahan dan pembibitan. Pengujian pada fase perkecambahan, dilihat dari paramater pertumbuhan tanaman (kecuali panjang akar) seluruh perlakuan jamur tanah yang ditambahkan dengan mikoriza menujukkan beda nyata dengan tanaman kontrol. Pada fase pembibitan, dilihat dari parameter pertumbuhan tanaman (kecuali tinggi tanaman) seluruh perlakuan jamur dengan penambahan mikoriza juga menunjukkan beda nyata dengan kontrol, kecuali pada perlakuan jamur Paecilomyces sp.
\end{abstract}

Kata kunci: Bibit pala, Jamur tanah, Mikoriza, Sclerotium rolfsii

\section{Abstract}

Death of seeds due to wilting disease of nutmeg seeds felt very harmful to the breeder nutmeg seeds. The purpose of this research is to know the type of organism that causes wilt disease on nutmeg seeds, to know the types of soil fungi that have the potential to suppress the development of nutmeg seed disease and to know the role of mycorrhizal in increasing plant resistance and growth. Research was conducted in in vitro, germination and breeding phase. The experimental design was Completely Randomized Design with three replications. The cause of nutmeg wilt disease is Slerotium rolfsii. A total of 15 soil fungal isolates obtained by exploration results. The results of the antagonism test showed that 11 fungi of soil potentially suppressed the S. rolfsii colony significantly. Four isolates of soil fungi, Candida sp, Trichoderma viride, Trichodrma harzianum, and Botrytis sp.1 consistently significantly suppressed the development of S. rolfsii on in vitro, germination and seeding test. With the addition of mycorrhizae, Botrytis sp. 2 was able to suppress the S. rolfsii significantly in the germination and seedling test. Tests on the germination phase, seen from plant growth parameters (except root length) all soil fungal treatments added with mycorrhiza showed significant differences with control plants. In the nursery phase, seen from plant growth parameters (except plant height) all fungal treatments with the addition of mycorrhiza also showed a significant difference with the control, except on the treatment of Paecilomyces sp.

Key words: Mycorrhiza, Nutmeg seeds, Sclerotium rolfsii, Soil fungi

Correspondence address:

Sarjoko

Email : sarjokobalaibesar@yahoo.com

Address : Program Magister Agronomi, Fakultas Pertanian, Universitas Brawijaya, Jl. Veteran,Malang 65145 


\section{PENDAHULUAN}

Beberapa peran penting jamur tanah antara lain menghasilkan enzim selulase yang berfungsi mengurai selulosa dinding sel patogen. Selain itu itu jamur tanah juga dilaporkan mampu meghambat perkembangan patogen tanaman baik dengan mekanisme kompetisi, mikoparasit maupun antibiosis. Beberapa jenis jamur tanah seperti Penicillium spp., Aspergillus spp.,Gliocladium sp., dan Trichoderma spp. dilaporkan mampu menekan perkembangan miselium Fusarium oxysporum [1].

Asosiasi mikoriza dengan tanaman telah banyak banyak dilaporkan mampu mengurangi kerusakan tanaman akibat serangan patogen [2]. Jamur mikoriza mampu berasosiasi dengan beberapa mikroba tanah yang biasa digunakan sebagai agen antagonis seperti Trichoderma, Gliocladium dan sebagainya [3]. Kombinasi perlakuan Trichoderma harzianum dan Trichoderma viride dengan jamur mikoriza memberikan hasil yang terbaik dalam menekan perkembangan jamur Puccinia graminis, jika dibandingkan dengan perlakuan secara sendiri-sendiri [4].

Telah banyak laporan yang menyebutkan bahwa patogen tular tanah terutama dari jenis jamur mampu menimbulkan kerugian yang cukup signifikan. Patogen tular tanah banyak menyerang tanaman pada fase pembibitan. Salah satunya adalah yang terjadi pada penangkaran bibit pala di Kecamatan Banda Provinsi Maluku pada tahun 2015. Dilaporkan bahwa $60 \%$ bibit mati dengan gejala tanaman layu dengan pangkal batang membusuk.

Keberadaan jamur tanah pada perkebunan pala dan peranan mikoriza dalam peningkatan ketahanan bibit pala terhadap penyakit layu bibit belum banyak dilaporkan. Sehingga perlu dilakukan kajian potensi jamur tanah dan mikoriza dalam menekan perkembangan penyakit layu bibit pada pala.

\section{METODE PENELITIAN \\ Tempat dan Waktu}

Penelitian dilaksanakan di Laboratorium Mikologi dan Rumah Kaca Balai Besar Perbenihan dan Proteksi Tanaman Perkebunan Ambon. Penelitian dilaksanakan mulai dari bulan September 2016 sampai dengan bulan Agustus 2017.

\section{Pelaksanaan Penelitian Pengujian di Laboratorium}

Eksplorasi jamur tanah diambil pada lahan pala yang sehat Desa Waling Spanciby Kecamatan Banda Kabupaten Maluku Tengah Provinsi Maluku. Seluruh jamur tanah yang berhasil diisolasi kemudian diuji daya antagonismenya terhadap jamur patogen dengan metode oposisi ganda.
Dari hasil uji antagonisme, jenis jamur tanah yang menunjukkan potensi sebagai agens antagonis selanjutnya diuji patogenisitasnya pada daun tembakau (sebagai media uji umum) dan pada biji pala. Jamur patogen diperbanyak dalam medium beras, dan dibungkus plastik dengan bobot 100 gram per bungkusnya. Jamur tanah yang berpotensi sebagai agens hayati diperbanyak dalam media PDA cair.

\section{Pengujian pada Fase Perkecambahan dan} Pembibitan

Media tanam yang sudah steril diinfestasi dengan jamur patogen. Dalam setiap polibag $20 \times 30$ $\mathrm{cm}$ diisi 2,5 kg media tanam diberikan jamur patogen sebanyak 50 gram kemudian diinkubasikan selama tujuh hari. Setelah itu aplikasi 2,5 ml jamur antagonis dengan kerapatan spora $10^{9}$ dilakukan bersamaan dengan penanaman biji pala. Pada pekecambahan, aplikasi mikoriza 20 gram dilakukan minggu keempat setelah tanam. Sedangkan pada fase pembibitan bersamaan dengan saat tanam bibit.

\section{Rancangan Percobaan}

Rancangan yang digunakan pada pengujian ini adalah Rancangan Acak Lengkap (RAL) dengan ulangan tiga kali. Dalam pengujian ini, jamur yang digunakan adalah 11 jenis jamur yang memiliki potensi sebagai agens antagonis berdasarkan uji antagonisme di laboratorium. Seluruh media tanam dalam pengujian ini sudah diinfestasi dengan jamur patogen. Sedangkan aplikasi mikoriza diberi kode M0 (tanpa aplikasi mikoriza) dan M1 (dengan aplikasi mikoriza).

\section{Pengamatan}

\section{Intensitas Serangan}

Intensitas serangan jamur S. rolfsii diperoleh dengan rumus jumlah bibit yang mati dibagi dengan total bibit yang diamati kemudian dikalikan $100 \%$.

\section{Pertumbuhan Tanaman}

Pengamatan pertumbuhan tanaman meliputi bobot basah akar, bobot kering akar, bobot basah tajuk dan bobot kering tajuk serta panjang akar yang dilakukan pada akhir pengamatan (14 MST).

\section{Analisis Data}

Data pengamatan yang diperoleh dianalisis dengan menggunakan analisis sidik ragam (uji F) pada taraf 5\% untuk mengetahui pengaruh perlakuan. Apabila hasilnya nyata maka dilanjutkan dengan uji Beda Nyata Terkecil (BNT).

\section{HASIL DAN PEMBAHASAN}

\section{Identifikasi Patogen Penyebab Penyakit Layu Bibit} Pala

Berdasarkan pengamatan pada gejala serangan, pengamatan biakan secara makroskopis dan mikroskopis di ketahui bahwa penyebab penyakit layu pada bibit pala adalah jamur Sclerotium rolfsii. Gejala pada kecambah pala terlihat terdapat benang- 
benang jamur berwarna putih seperti bulu. Benangbenang ini kemudian membentuk sklerotium. Bagian tanaman yang terinfeksi pangkal batangnya akan bewarna coklat gelap dikelilingi oleh sklerotia yang berbentuk butiran kecil.

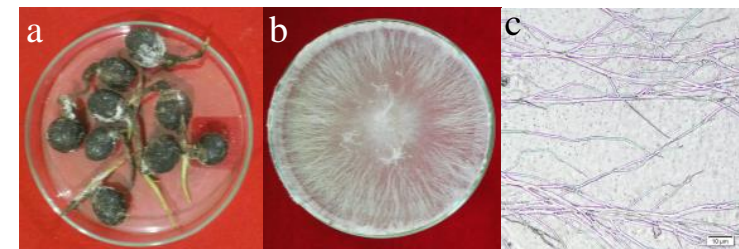

Gambar 1. Gejala serangan S. rolfsii pada kecambah pala (a), penampakan biakan secara makroskopis (b) dan mikroskopis (c)

Berdasarkan Gambar 1, secara makroskopis, menunjukkan bahwa biakan jamur mempunyai miselium yang menyerupai benang, berwarna putih tersusun seperti bulu atau kapas. Jamur ini tidak membentuk spora untuk pemencaran dan mempertahankan diri, jamur membentuk sklerotium yang semula berwarna putih, kelak menjadi coklat, dengan garis tengah $\pm 1 \mathrm{~cm}$. Dilihat secara mikroskopis, hifa sekunder tumbuh di bawah sekat pangkal dan sering tumbuh menempel pada hifa primer. Cabang tersier dan seterusnya berukuran lebih sempit, mempunyai lebar antara 1,6-2,0 $\mu \mathrm{m}$ dengan sel-sel yang pendek, percabangan membentuk sudut yang besar. S. rolfsii memiliki koloni berwarna putih dengan banyak untaian hifa,sel hifa primer yang berkembang di tepi koloni mempunyai lebar 4-9 $\mu \mathrm{m}$ [4].

\section{Identifikasi dan Uji Antagonisme Jamur Tanah}

Dari hasil eksplorasi isolasi jamur tanah, diperolah 15 jenis isolat. Setalah diidentifikasi secara makroskopis dan mikroskopis, diketahui jenis isolatisolat tersebut adalah Trichoderma viride, Botrytis sp.1, Trichoderma harzianum, Aspergillus sp.1, Aspergillus sp.2, Candida sp, Botrytis sp.2, Aspegillus niger, Aspergillus sp.3, Acremonium sp, Colletotricum $\mathrm{sp}$, Paecilomyces sp, Humicola sp.1, Hyalodendron sp, dan Humicola sp. 2.

Dari hasil uji antagonisme terhadap jamur $S$. rolfsii, terdapat 11 jenis jamur yang berbeda nyata dengan kontrol. Jamur tersebut adalah $T$. viridae, Candida sp, Botrytis sp.2, Paecilomyces sp, Botrytis sp.1, Humicola sp.2, Aspergillus sp.1, Humicola sp. 1 Hyalodendron sp, T. harzianum dan Aspergillus sp.3. Sedangkan jamur yang menunjukkan tidak ada beda nyata dengan kontrol adalah A. niger, Fusarium sp, Aspergillus sp. 2 dan Collelotricum sp.

\section{Patogenisitas Jamur Tanah Terhadap Daun Tembakau dan Biji Pala \\ Hasil pengamatan pada daun tembakau dan} biji pala, diketahui bahwa sebelas jamur tanah yang diujikan tidak bersifat patogenik terhadap tanaman. Pada daun tembakau tidak dijumpai nekrosis sebagai gejala toksisitas tanaman. Pada biji pala, seluruhnya berkecambah dengan baik dan normal. Rata-rata biji pala berkecambah pada minggu keempat dan kelima setelah tanam. Selanjutnya 11 tersebut diuji potensinya pada perkecambahan dan pembibitan pala.

\section{Potensi Jamur Tanah dalam Menekan Intensitas Serangan Jamur S. rolfsii Pada Fase Perkecambahan dan Pembibitan \\ Pengujian pada fase perkecambahan pala} menunjukkan bahwa dari 11 jamur yang diuji, terdapat lima jenis yang mampu menekan intensitas serangan S. rolfsii secara signifikan dan berbeda nyata dengan kontrol, seperti yang terlihat pada Tabel 1. Urutan lima jenis jamur tanah dari yang terkuat nilai penekanannya adalah $T$. viride dengan intensitas serangan $18,52 \%$, diikuti oleh $T$. harzianum sebesar $22,22 \%$. Selanjutnya Botrytis sp dengan intensitas serangan 25,93\%, kemudian Candida sp serta Humicola sp. 2 sebesar $29,63 \%$.

Tabel 1. Pengaruh jamur tanah dan mikoriza terhadap intensitas serangan $S$. rolfsii pada pengujian fase perkecambahan dan pembibitan pala pada 14 MST

\begin{tabular}{|c|c|c|c|c|}
\hline \multirow{2}{*}{ Perlakuan } & \multicolumn{4}{|c|}{ Intensitas serangan (\%) } \\
\hline & \multicolumn{2}{|c|}{ Perkecambahan } & \multicolumn{2}{|c|}{ Pembibitan } \\
\hline Kontrol & 62,96 & a & 59,26 & a \\
\hline T. viride & 18,52 & bc & 14,81 & de \\
\hline Botrytis sp.1 & 25,93 & $\mathrm{~b}$ & 18,52 & cde \\
\hline T. harzianum & 22,22 & bc & 22,22 & $\mathrm{~cd}$ \\
\hline Aspergillus sp.1 & 51,85 & a & 51,85 & $a b$ \\
\hline Candida sp & 29,63 & $b$ & 18,52 & cde \\
\hline Botrytis sp. 2 & 59,26 & a & 48,15 & $a b$ \\
\hline Aspergillus sp.3 & 62,96 & a & 55,56 & $a b$ \\
\hline Paecilomyces sp & 55,56 & a & 48,15 & $a b$ \\
\hline Humicola sp 1 & 48,15 & a & 51,85 & $a b$ \\
\hline Hyalodendron sp & 51,85 & a & 55,56 & $a b$ \\
\hline Humicola sp. 2 & 29,63 & $b$ & 44,44 & $a b$ \\
\hline Konsorsium & & & 25,93 & C \\
\hline Kontrol + M & 48,15 & $a$ & 55,56 & $a b$ \\
\hline T. viride + $\mathrm{M}$ & 11,11 & C & 11,11 & e \\
\hline Botrytis sp.1 + M & 18,52 & bc & 18,52 & cde \\
\hline T. harzianum + M & 14,81 & bc & 14,81 & de \\
\hline Aspergillus sp.1 + M & 48,15 & a & 51,85 & $a b$ \\
\hline Candida sp + M & 14,81 & bc & 25,93 & c \\
\hline Botrytis sp.2 + M & 25,93 & $\mathrm{~b}$ & 22,22 & $\mathrm{~cd}$ \\
\hline Aspergillus sp.3 + M & 48,15 & a & 48,15 & $a b$ \\
\hline Paecilomyces sp + M & 18,52 & bc & 55,56 & $a b$ \\
\hline Humicola sp 1 + M & 44,44 & a & 51,85 & $a b$ \\
\hline Hyalodendron $\mathrm{sp}+\mathrm{M}$ & 14,81 & bc & 44,44 & $a b$ \\
\hline Humicola sp. $2+\mathrm{M}$ & 25,93 & $\mathrm{~b}$ & 48,15 & $a b$ \\
\hline Konsorsium + M & & & 18,52 & cde \\
\hline
\end{tabular}

Keterangan : + M adalah penambahan mikoriza. Data ditransformasi dengan akar $x+0,5$

Enam jenis jamur yang tidak berbeda nyata dengan kontrol adalah Aspergillus sp.1, Botrytis sp.2, 
Aspergillus sp.3, Paecilomyces sp, Humicola sp.1 dan Hyalodendron sp.

Pengujian pada fase pembibitan, terdapat empat jenis jamur dan satu konsorsium yang secara signifikan menekan intensitas serangan $S$. rolfsii dan berbeda nyata dengan kontrol. Jamur $T$. viride menekan paling kuat dengan intensitas serangan 14,81\%, diikuti oleh jamur Botrytis sp.1 dan Candida sp dengan intensitas serangan $18,52 \%$ dan selanjutnya $T$. harzianum dengan intensitas serangan $22,22 \%$. Konsorsium jamur yang mampu menekan kematian bibit dengan intensitas serangan sebesar $22,93 \%$. Tujuh jenis jamur yang tidak berbeda nyata dengan kontrol adalah Aspergillus sp.1, Botrytis sp.2, Aspergillus sp.3, Paecilomyces sp, Humicola sp.1, Hyalodendron sp dan Humicola sp.2.

\section{Mekanisme penekanan jamur tanah terhadap jamur S. rolfsii}

Dilihat dari pengujian in vitro di laboratorum, fase perkecambahan dan pembibitan, terdapat empat jenis jamur yang secara konsisten mampu meneka perkembangan jamur $S$. rolfsii. Keempat jamur tersebut adalah Candida sp, T. viride, T. harzianum, dan Botrytis sp.1. Jamur T. viride dan T. harzianum menekan jamur $S$. rolfsii dengan mekanisme antibiosis, sedangkan jamur Candida sp dan Botrytis sp.1 dengan mekanisme mikoparasit.

\section{Antibiosis}

$T$. viride dan $T$. harzianum menekan S. rolfsii dengan mekanisme antibiosis. Hal ini ditandai dengan adanya zona bening yang terbentuk pada pertemuan kedua koloni jamur. Antibiosis dapat terjadi karena jamur tanah mampu memproduksi beberapa senyawa antibiotik yang berfungsi menghambat perkembangan patogen.

Jamur T. harzianum mampu memproduksi asam nonanoat yang berfungsi dalam menghambat perkecambahan spora jamur patogen. Jamur $T$. harzianum juga menghasilkan senyawa trichodermin, senyawa antijamur yang mampu menghambat sintesis protein selama perkecambahan spora patogen. Selain itu $T$. harzianum juga mampu menghasilkan beberapa senyawa antijamur yaitu asam 3-deoksi-d-manoik, 5-hidroksimetilfurfural, asam suksinat, 1,2,3-propanetriol monoasetat, 1,3-15 dihidroksiaseton, asam L-laktat, asam butanoik, dan asam valerik [5].

Jamur $T$. viride mampu menghasilkan senyawa viridin, viridiol, 10 gliotoksin, gliovirin dan dermadin mampu mencegah terjadinya perkecambahan spora beberapa jamur patogen. Selain itu $T$. viride juga menghasilkan asam L-Laktat organik yang diketahui sebagai senyawa antijamur. Asam levulinat, asam format, asam asetat merupakan produk senyawa antijamur lainnya yang diproduksi oleh jamur T. viride [5].

\section{Mikoparasit}

Selain selain mekanisme antibiosis, jamur tanah juga menghambat perkembangan jamur $S$. rolfsii dengan mekanisme mikoparasit, seperti yang terjadi pada jamur Candida $s p$. Mikoparasit dapat terjadi karena jamur tanah mampu memproduksi beberapa enzim yang dapat mendegradasi lapisan sel patogen.

Jamur Candida sp mampu menghasilkan enzim kitinase [6]. Enzim kitinase berfungsi sebagai pendegradasi senyawa kitin pada dinding sel jamur patogen penyebab penyakit tumbuhan [7]. Dinding sel hifa jamur $S$. rolfsii salah satunya senyawa penyusunnya adalah kitin. Dengan terdegradasinya senyawa kitin oleh enzim kitinase maka petumbuhan jamur $S$. rolfsii menjadi terhambat atau bahkan mengalami kematian. Hal tersebut akan mengakibatkan turunnya intensitas serangan S. rolfsii pada tanaman inang.

\section{Peranan Mikoriza dalam Meningkatkan Ketahanan Tanaman}

Dilihat dari hasil pengujian pada fase perkecambahan, terdapat enam jenis jamur yang tidak berbeda nyata dengan kontrol. Namun pada perlakuan dengan penambahan mikoriza, jamur Hyalodendron sp dengan intensitas serangan $18,52 \%$, diikuti Pecilomyces sp sebesar 18,52\% serta Botrytis sp. 2 dengan intensitas serangan 25,93\% mampu menekan intensitas serangan $S$. rolfsii secara signifikan. Sedangkan pada pengujian fase pembibitan terdapat tujuh jenis jamur yang tidak berbeda nyata dengan kontrol. Namun jika perlakuan ditambah dengan mikoriza terdapat satu jenis jamur, yaitu Botrytis sp.2 dengan intensitas serangan $S$. rolfsii sebesar 22,22 \% dan berbeda nyata dengan kontrol. Hal ini mengindikasikan bahwa dengan adanya penambahan mikoriza mampu meningkatkan ketahanan tanaman dari serangan jamur S. rolfsii.

Mikoriza dapat melindungi akar tanaman dengan menginfeksi korteks akar tanaman. Selain itu juga membantu tanaman menyerap nutrisi yang dibutuhkan oleh tanaman, sehingga meningkatkan resistensi tanaman terhadap $S$. rolfsii dengan melepaskan senyawa yang dapat mencegah infeksi oleh patogen seperti fenol dan fitoaleksin [8].

Akumulasi senyawa seperti senyawa fenolik dan hormon fitoaleksin adalah tanda adanya respon pertahanan pada tanaman sehat [9]. Senyawa fenol yang ditemukan dalam kacang yang telah diinokulasi dengan mikoriza dapat menghambat pertumbuhan $S$. rolfsii secara in vitro [8]. Tanaman tomat yang diinokulasi dengan mikoriza dapat meningkatkan toleransi terhadap Fusarium oxysporum f.sp. 
Tabel. 2. Pengaruh jamur tanah dan mikoriza terhadap pertumbuhanan tanaman pala pada pengujian fase perkecambahan umur 14 HST

\begin{tabular}{|c|c|c|c|c|c|c|c|c|c|c|c|c|}
\hline \multirow[t]{2}{*}{ Perlakuan } & \multicolumn{2}{|c|}{$\begin{array}{l}\text { Panjang Akar } \\
\text { (cm) }\end{array}$} & \multicolumn{2}{|c|}{$\begin{array}{c}\text { Bobot } \\
\text { Basah Akar } \\
\text { (gr) }\end{array}$} & \multicolumn{2}{|c|}{$\begin{array}{c}\text { Bobot } \\
\text { Kering Akar } \\
\text { (gr) }\end{array}$} & \multicolumn{2}{|c|}{$\begin{array}{c}\text { Bobot Basah } \\
\text { Tajuk (gr) }\end{array}$} & \multicolumn{2}{|c|}{$\begin{array}{l}\text { Bobot Kering } \\
\text { Tajuk (gr) }\end{array}$} & \multicolumn{2}{|c|}{$\begin{array}{l}\text { Tinggi Tanaman } \\
\text { (cm) }\end{array}$} \\
\hline & 6,167 & $f$ & 0,663 & e & 0,133 & $f$ & 1,140 & $\mathrm{e}$ & 0,252 & $\mathrm{e}$ & 18,667 & $d$ \\
\hline T. viride & 13,806 & a & 1,829 & $b$ & 0,366 & $a b c$ & 3,011 & bc & 0,670 & $a b c$ & 23,889 & a \\
\hline Botrytis sp.1 & 13,750 & a & 1,879 & $a b$ & 0,370 & $a b c$ & 2,986 & bc & 0,662 & bc & 23,361 & $a b$ \\
\hline T. harzianum & 13,833 & a & 1,866 & $b$ & 0,377 & $a b c$ & 3,360 & $a b$ & 0,746 & $a b c$ & 23,500 & $a$ \\
\hline Aspergillus sp.1 & 6,433 & $f$ & 0,675 & e & 0,133 & $f$ & 1,161 & $\mathrm{e}$ & 0,257 & $\mathrm{e}$ & 19,417 & $\mathrm{~cd}$ \\
\hline Candida sp & 13,906 & a & 1,849 & $b$ & 0,369 & $a b c$ & 2,846 & bc & 0,632 & c & 23,694 & $\mathrm{a}$ \\
\hline Botrytis sp. 2 & 6,167 & $f$ & 1,026 & $d$ & 0,252 & $\mathrm{e}$ & 2,792 & $\mathrm{C}$ & 0,620 & c & 22,917 & $a b c$ \\
\hline Aspergillus sp.3 & 6,500 & ef & 0,651 & e & 0,139 & $f$ & 1,144 & $\mathrm{e}$ & 0,255 & $\mathrm{e}$ & 19,500 & bcd \\
\hline Paecilomyces sp & 6,517 & def & 0,669 & e & 0,132 & $f$ & 1,165 & $\mathrm{e}$ & 0,260 & $\mathrm{e}$ & 18,917 & $\mathrm{~d}$ \\
\hline Humicola sp 1 & 9,178 & bcd & 0,697 & e & 0,142 & $f$ & 1,158 & $\mathrm{e}$ & 0,258 & $\mathrm{e}$ & 18,833 & $d$ \\
\hline Hyalodendron sp & 9,156 & bcde & 0,668 & e & 0,140 & $f$ & 1,167 & & 0,257 & e & 18,889 & $d$ \\
\hline Humicola sp. 2 & 14,800 & a & 1,842 & b & 0,363 & $a b c$ & 2,801 & c & 0,625 & c & 23,333 & $a b$ \\
\hline Kontrol + mikoriza & 10,333 & $b$ & 1,229 & $\mathrm{~cd}$ & 0,249 & $\mathrm{e}$ & 1,847 & & 0,409 & $d$ & 22,917 & $a b c$ \\
\hline T. viride + mikoriza & 13,778 & a & 2,107 & a & 0,424 & a & 3,640 & $\mathrm{a}$ & 0,815 & $\mathrm{a}$ & 24,139 & a \\
\hline Botrytis sp.1 + mikoriza & 13,611 & a & 1,925 & $a b$ & 0,385 & $a b c$ & 3,290 & $a b c$ & 0,743 & $a b c$ & 23,722 & a \\
\hline T. harzianum + mikoriza & 13,833 & a & 2,056 & $a b$ & 0,413 & $a b$ & 3,716 & & 0,801 & $a b$ & 23,722 & a \\
\hline Aspergillus sp.1 + mikoriza & 10,500 & $\mathrm{~b}$ & 1,138 & $\mathrm{~cd}$ & 0,229 & $\mathrm{e}$ & 1,822 & & 0,411 & $d$ & 23,083 & $a b c$ \\
\hline Candida $s p+$ mikoriza & 13,611 & a & 2,006 & $a b$ & 0,400 & $a b c$ & 2,917 & bc & 0,666 & bc & 23,972 & $\mathrm{a}$ \\
\hline Botrytis sp. $2+$ mikoriza & 10,528 & b & 1,127 & $\mathrm{~cd}$ & 0,223 & $\mathrm{e}$ & 1,851 & & 0,414 & $d$ & 22,889 & $a b c$ \\
\hline Aspergillus sp.3 + mikoriza & 7,500 & cdef & 1,346 & c & 0,273 & de & 1,792 & & 0,421 & $d$ & 19,250 & $\mathrm{~cd}$ \\
\hline Paecilomyces sp +mikoriza & 7,083 & cdef & 1,030 & $d$ & 0,224 & $\mathrm{e}$ & 1,860 & & 0,414 & $d$ & 22,944 & $a b c$ \\
\hline Humicola sp 1 +mikoriza & 9,667 & bc & 1,039 & $d$ & 0,221 & $\mathrm{e}$ & 1,754 & $d$ & 0,412 & $d$ & 23,000 & $a b c$ \\
\hline Hyalodendron sp + mikoriza & 10,250 & $\mathrm{~b}$ & 1,227 & $\mathrm{~cd}$ & 0,331 & $\mathrm{~cd}$ & 1,828 & $d$ & 0,409 & $\mathrm{~d}$ & 23,083 & abc \\
\hline Humicola sp. $2+$ mikoriza & 13,778 & a & 1,913 & $a b$ & 0,341 & bcd & 3,097 & bc & 0,634 & c & 24,333 & $\mathrm{a}$ \\
\hline
\end{tabular}

lycopersici dengan meningkatkan sintesis lignin [10]. Terbentuknya arbuskular, vesikula, dan jaringan hifa intraseluler di dalam korteks tanaman menyebabkan tidak tersedianya ruang untuk patogen dan mengurangi pasokan karbohidrat patogen di akar tanaman [11].

\section{Peranan Mikoriza dalam Meningkatkan \\ Pertumbuhan Tanaman}

Mikoriza berpengaruh cukup besar terhadap pertumbuhan tanaman. Hal ini dapat dilihat dari hasil pengamatan pada pengujian fase perkecambahan seperti yang terlihat pada Tabel 2 . Pada fase perkecambahan, dengan parameter bobot basah akar, bobot kering akar, bobot basah tajuk dan bobot kering tajuk dan tinggi tanaman enam jenis jamur yang berbeda nyata dengan kontrol adalah $T$. viride, Botrytis sp.1, T. harzianum, Candida sp, Botrytis sp.2 dan Humicola sp.2.

Sedangkan lima jenis jamur yang tidak berbeda nyata dengan kontrol adalah Aspergillus sp.1, Aspergillus sp.3, Paecilomyces sp, Humicola sp.1 dan Hyalodendron sp. namun seluruh perlakuan jamur menjadi berbeda nyata saat dilakukan penambahan mikoriza.

Pada pengujian fase perkecambahan, dilihat dari paramater pertumbuhan tanaman (tinggi tanaman, bobot basah akar, bobot kering akar, bobot basah tajuk dan bobot kering tajuk) seluruh perlakuan jamur tanah yang ditambahkan dengan mikoriza menujukkan beda nyata dengan tanaman kontrol. Sedangkan pada fase pembibitan, dengan paramater pertumbuhan tanaman (panjang akar, bobot basah akar, bobot kering akar, bobot basah tajuk dan bobot kering tajuk) seluruh perlakuan jamur dengan penambahan mikoriza juga menunjukkan beda nyata dengan kontrol, kecuali pada perlakuan jamur Paecilomyces sp. Hal ini menunjukkan bahwa mikoriza berperan penting dalam mempengaruhi pertumbuhan tanaman, dibandingkan dengan tanaman yang tidak diberi mikoriza.

Tanaman yang diberi mikoriza secara siginifikan lebih tinggi dibandingkan dengan tanaman yang tidak diberi mikoriza. Hal ini terjadi karena mikoriza membantu tanaman dalam penyerapan air dan unsur hara untuk kebutuhan fotosintesis. Selain itu mikoriza juga memicu peningkatan hormon sitokinin dan auksin. Kedua hormon tersebut berperan dalam diferensiasi dan perpenjangan sel, sehingga tanaman menjadi lebih tinggi [12].

Hifa mikoriza dapat memperpanjang zona jangkauan perakaran tanaman sehingga meningkatkan penyerapan unsur mikro yang dibutuhkan tanaman [13]. Mikoriza dapat 
meningkatkan proses fotosintesis pada daun [14]. Beberapa tanaman seperti jagung, bawang merah, semangka, kedelai, cabai dan tomat menunjukkan bahwa tanaman diinokulasi dengan jamur mikoriza memberikan pertumbuhan dan hasil yang lebih baik daripada tanaman yang tidak diinokulasi [8]. Kombinasi mikoriza dengan kompos kotoran sapi pada tanaman jagung berkontribusi secara signifikan mampu meningkatkan sifat kimia tanah, terutama untuk total C-organik, N, P-tersedia dan K [15].

\section{KESIMPULAN}

Penyebab penyakit layu pada bibit tanaman pala adalah jamur Sclerotium rolfsii. Empat jenis jamur yang potensial menekan perkembangan jamur S. rolfsii yaitu yaitu Botrytis sp.1, Candida sp, Trichoderma viride, dan Trichoderma harzianum. Mikoriza mampu meningkatkan ketahanan bibit pala terhadap serangan jamur S.rolfsii.

\section{UCAPAN TERIMA KASIH}

Penulis menyampaikan terima kasih kepada Kementerian Pertanian Republik Indonesia yang telah memberikan beasiswa untuk melaksanakan tugas belajar.

\section{DAFTAR PUSTAKA}

[1]. Sudarma, I M. and D.N. Suprapta. 2011. Diversity of soil microorganism in banana habitats with and without Fusarium wilt Symptom. J. ISSAAS 17(1) : 147s-159s

[2]. Azcon-Aguilar, C. and J.M. Barea. 1996. Arbuscular mycorrhizas and biological control of soil-borne plant pathogens-an overview of the mechanisms involved. Mychorrhyza 6 : 457s$464 \mathrm{~s}$

[3]. Linderman, R. G. 1996. Role of VAM Fungi In Biocontrol. Mycoorhizal and Plant Health. APS Press. Minnesota. p.1-25

[4]. El-Sharkawy, H.H.A., Rashad, Y.M. and Ibrahim, S.A. 2018. Biocontrol of stem rust disease of wheat using arbuscular mycorrhizal fungi and Trichoderma spp. Physiol.and Molec. Plant Pathol. A Manuscript.

[5]. Semangun, H. 1994. Penyakit-penyakit tanaman pangan di Indonesia. Gadjah Mada University Press. Yogyakarta.Hasan, A.A., Noha, and H. Nobari. 2015. Efficacy of Chitinolytic Enzyme Produced by Some Soil Fungi (Candida albicans and Aspergillus fumigats) ini Biologycal Control of Cattle Ticks. Inter. J. of Res. Stud. in Biosci. 3 (2). 7S-13S

[6]. El-Katatny MH, Gudelj M, Robra KH, Elnaghy MA, Gübitz GM. 2001. Characterization of chitinase and an endo-beta-1,3-glucanase from Trichoderma harzianum Rifai T24 involved in control of phytopatogen Sclerotium rolfsii. Appl. Microbiol. Biotech. 56 :137-143

[7]. Sastrahidayat, I.R., S. Djauhari, A. Muhibuddin dan N, Saleh. 2011. Control of "Damping off" Disease Caused by Sclerotium rolfsii.Using Actinomycetes and VAM Fungi on Soybean in the Dry Land Based on Microorganism Diversity of Rhizosphere Zone. Agrivita. 3 (1). 40S-46S

[8]. Elsen A., H. Baimey R. Swennen dan D. De Waele. 2003. Relative Mycorrhizal Dependency and Mycorrhiza-Nematode Interaction in Banana Cultivars (Musa spp.) Differing in Nematode Susceptibility. Plant and Soil. 256. 303S-313S

[9]. Caron M. 1989. Potential use of Mycorrhizae in Control of Soil-Borne Diseases. Canadian J. of Plant Pathol. 1. 177S-179S

[10]. Muhibuddin, A. 2007. Model matematik populasi vesicular arbuscular Mycorrhizae (VAM) pada pergiliran tanaman jagung dan kedelai di Jatikerto. AGRIVITA. 29 (2). 97S-105S

[11]. Wahyu, E.r., K.I. Purwani, S. Nurhatika dan A. Arifiyanto. 2013. Bioassay of Glomus fasciculatum Against Pathogenic Fungi Sclerotium rolfsii in Glycine max L. Merril. Var. Argomulyo. J. Agric. Food. Tech. 3(6). 1S-7S

[12]. Turk M. A., T. A. Assaf, K. M. Hameed dan A. M. Al-Tawaha. 2006. Significance of Mycorrhizae. World J. of Agric. Sci. 2 (1). 16S-20S

[13]. Sheng M., T. Ming H. Chen B. Yang F. Zhang dan Y. Huang. 2008. Influence of arbuscular mycorrhizae on photosynthesis and water stats of maize plants under salt stress. Mychorrhiza 18. 287S-296S

[14]. Astiko, W., I.R. Sastrahidayat, S. Djauhari, dan A. Muhibuddin. 2013. The Role of Indigenous Mycorrhiza in Combination with Cattle Manure in Improving Maize Yield (Zea Mays L) on Sandy Loam of Northern Lombok, Eastern of Indonesia. J. Trop. Soils. 18 ( 1). 53S-58S 